\title{
FAKTOR PENYEBAB PERUBAHAN IDENTITAS DIRI PADA WARIA DI DESA SAPEKEN
}

\author{
Eko Mulyadi, Program Studi Ilmu Keperawatan UNIJA Sumenep \\ e-mail: eko.wiraraja@gmail.com \\ Nelyta Oktavianisya, Program Studi Ners UNIJA Sumenep \\ e-mail: nelyta2516@gmail.com
}

\begin{abstract}
Transgender person is an individual who thinks and feels differently from the assigned gender; it is classified as a gender identity disorder; in this study context is a man who changed himself to be a woman. This uncommon behavior struggles for social acceptance in Indonesian society due to gender construction debate. This aim of this study was todetermine the factors that affect the change of self identity in transvestites in the village sapeken.

This study used a qualitative approach. Data collected by using interviews, observation, documentation, and DASS tests. The informants were collected using the snowball technique with 5 informants, 4 families, and 1 community leaders. In this research used source triangulation technique as data checking technique.

Based on the results of research and data analysis, it is known that the factors that influence the change of self identity in transvestites are (1) parental care pattern; Parents forbid their children associate with women but parents do not forbid their children associate with waria. (2) psychiatric disorders; Based on the results of the Depression Anxiety Stress Scale (DASS) test and in-depth interviews, the informants experienced mild depression. (3) sexual violence; Sexual violence often occurs in transsexuals but they are unaware of how the process of sexual violence takes place, in fact they enjoy sexual violence against them.

Parents are instrumental in determining the personality of the child, the role is given in the benediction of good parenting, giving direction to their children and communicate while doing parenting activities. So that children feel cared for by parents who later will form the child's personality in accordance with the expectations of parents.
\end{abstract}

Keywords: Change of self identity, Transvestites.

\section{PENDAHULUAN}

Waria sebenarnya manusia yang secara fisik merupakan lelaki normal dengan jenis kelamin normal, tetapi mereka merasa dirinya adalah perempuan. Identitas gender berhubungan dengan aspek psikologis, yaitu bagaimana seseorang memutuskan mengartikan identitas seksual untuk dirinya atau citra diri seksual (sexual self-image) dan konsep diri. Secara singkat identitas seksual seseorang bisa di lihat dari kemampuan memahami sexual identity (identita kelamin), gender identity (identitas jenis kelamin) dan gender role behaviour (perilaku peranan jenis kelamin) (Andarmoyo, 2014). Berdasarkan survei pendahuluan yang peneliti lakukan pada Januari 2017, perubahan prilaku pada waria didesa sapeken terjadi sejak usia sekolah, perubahan ini didasari karena adanya dukungan dari sesama pria trangender serta masyarakat sehingga mereka merasa puas hidup sebagai seorang pria trangender.

Keputusan untuk menjadi waria melalui proses yang tidak mudah dan relative panjang. Meskipun pria transgenderatau wariamenyadari bahwa kepuusannya dikemudian hari akan banyak memabawanya ke berbagai permasalahan, seperti canggungterhadap identitas, serta mereka cenderung tidak akan diterima di lingkungan masyarakat karena pertentangan gender (Sutarmanto \& Putri, 2007). Transseksual merupakan individu yang secara genetik dan anatomis merupakan pria atau wanita, tetapi menganggap dirinya memiliki pikiran seperti jenis kelamin yang berbeda dari dirinya dan dengan berbagai cara 
berusaha mengubah jenis kelamin secara legal baik pengobatan hormonal ataupun pembedahan (Stuart, 2013).

Berdasarkan penelitian yang dilakukan Gates (2011), didapatkan jumlah perempuan biseksual di Amerika serikat sebanyak 2,2\% dari total penduduk (2.648.033), lesbian 1,2\% (1.359.801), pria biseksual1,4 (1.519.912), pria gay 2,2\% (2.491.034), dan waria sebanyak 0,3\% (697.529). Berdasarkan data Kementrian Sosial RI (2012), jumala waria di 33 provinsi di Indonesia adalah 31.179 jiwa. Dari 33 provinsi tersebut Jawa Timur menempati urutan pertama dalam jumlah waria pada tahun 2012 dengan jumlah 4.170 jiwa dan diikuti Provinsi Jawa Barat sebanyak 2.871 jiwa, sementara Provinsi Sulawesi Barat dan Provinsi Jambi menempati urutan terakhi yaitu 0 jiwa. Berdasarkan hasil observasi peneliti di Desa Sapeken, terdapat 16 responden yang memilih merubah identitas dirinya menjadi seorang waria. Terdapat kemiripan perilaku yang tampak dari 3 responden yaitu selalu bermain dengan wanita.

Menurut penelitian yang dilakukan Ruhghea (2014), bahwa Pria transgender mengalami gangguan identitas diri sejak masih anak-anak sehingga mereka merasakan pertentangan pada dirinya, sehingga mereka tidak mampu bertingkah laku seperti lelakisepertiumumnya. Berdasarkan hasil penelitian Faidah dan Abdullah (2013), menyatakan ada tiga faktor utama terlibat dalam perubahan identitas seorang lelaki menjadi waria, yaitu (1) secara kejiwaan, lelaki yang akhirnya menisbahkan diri menjadi waria lebih nyaman menjadi wanita; (2) pola asuh, perlakuan dan pendidikan yang diberikan orangtua serta penerimaan lingkungan sejak usia dini; dan (3) kekerasan seksual yang pernah diterima, berupa hubungan seksual sesama jenis (sodomi), korban yang akhirnya menjadi waria berperan sebagai wanita.

Identitas gender mulai berkembang sejak umur 2 sampai 3 tahun yang dipengaruhi oleh faktor biologis (embrionik dan sistem saraf pusat), anatomi kelamin, dan bagaimana pola asuh kedua orang tua kepada anaknya. Seksualitas tidak terbatas hanya hubungan seksual di tempat tidur atau bagian tubuh saja, tetapi bagaimana seseorang menggambarkan pribadinya dalam tingkah laku, perasaan fisik dan juga simbolik tentang kemesraan, mengahargai serata saling perhatian secara timbal balik (Hamid, 2009)

Agar berguna secara efektif dalam peran, mereka harus tahu perilaku dan nilai yang diinginkan, mempunyai kemauan dalam memastikan perilaku dan nilai tersebut, dan tuntutan peran harus terpenuhi (Potter dan Perry, 2010). Berdasarkan hal yang melatarbelatangi diatas menjadi dasar peneliti untuk melakukan penelitian tentang "Faktorfaktor yang mempengaruhi Perubahan Identitas Diri pada Waria di Desa Sapeken".

\section{METODE PENELITIAN}

Desain penelitian yang aplikasikan pada penelitan ini adalah deskriptif kualitatif fenomenologi yang bertujuan untuk memperoleh pemahaman yang menyeluruh dan tuntas mengenai faktor penyebab perubahan identitas diri waria. Penelitian ini brtujuan untuk mengetahui faktor penyebab perubahan identitas diri pada waria di Desa Sapeken, Kec. Sapeken, Kab. Sumenep. Sampel penelitian diperoleh dengan tekhnik snowball sampling.

Populasi penelitian ini adalah semua Waria di Desa Sapeken Tahun 2017 yaitu sebanyak 16 orang. Informan yang terlibat dalam penelitian ini yaitu masyarakat di Desa Sapeken, Kecamatan Sapeken, Kabupaten Sumenep. Informan yang dipilih adalah waria berusia 15 sampai 30 tahun sebanyak 5 orang, keluarga waria sebanyak 4 orang dan 1 tokoh masyrakat. Jumlah keseluruhan informan yaitu 10 orang.

Pada tahap awal peneliti mengunjungi Desa Sapeken, Kecamatan Sapeken untuk lebih dahulu meminta ijin kepada kepala Desa Sapeken, Kecamatan Sapeken selaku gatekeeper dalam penelitian ini. Dalam penelitian ini, peneliti juga menemui tokoh agama dan tokoh masyarakat yang dianggap key person dalam penelitian ini. Selanjutnya peneliti melakukan diskusi dengan tokoh masyarakat dan tokoh agama untuk menentukan informan dan menentukan tempat wawancara. Setelah melaukan diskusi dan kesepakatan pada key person, peneliti melakukan wawancara mendalam pada waria sesuai dengan pedoman wawancara. Peneliti melakukan observasi selama mengunjungi Desa Sapeken dan mengamati keseharian beberapa waria. Selain itu, peneliti juga bertanya kepada keluarga waria 
yang dianggap dan dipercaya mengetahui latar belakang identitas diri pada waria di Desa Sapeken.

\section{HASIL PENELITIAN}

\section{Pola Asuh Orang Tua}

a. Kurangnya perhatian dari orang tua dalam mengasuh anaknya

Berdasarkan hasil wawancara, mereka (waria) mengungkapkan bahwa orang tua mereka membiarkan mereka menjadi anak yang bebas tanpa pengawasan dari orang tua. Sesuai dengan pernyataan informan:

"larangan ne jedu ku le emma ku, parebean ne ku soho ne daha battitu beananku ye, gai ku pabeane kukuri beke dende tapi pabea ne ku pupok beke kkb" (sebenarnya orang tua saya melarang saya, memarahi saya, jangan seperti itu saya turuti saja. Saya juga dilarang bergaul dengan perempuan tapi tidak dilarang bergaul dengan sesama waria). Sedangkan dari hasil wawancara mendalam yang dilakukan terhadap keluarga didapatkan pernyataan di bawah ini:

"lebba jedu di pabaun ye. Tapi sanggah sekedar dipabaun"(kadang dia dikasi tau, tapi Cuma sekedar dikasi tau).

Dari hasil observasi, kebanyakan waria di Desa Sapeken hidup terpisah dengan keluarga sehingga mereka lebih sering berkumpul dengan sesama waria daripada dengan keluarga. Hal ini dapat dilihat dari keseharian mereka yang lebih sering menghabiskan waktu bersama dengan sesama waria, bahkan dari segi pekerjaan kebanyakan dari mereka bekerja sebagai tukang hias pengantin.

Berdasarkan pernyataan di atas maka dapat disimpukan bahwa karakter anak ditentukan oleh peran dari kedua orang tuanya. Anak menjadi anak yang bebas tanpa pengawasan dari orang tuanya mempresepsikan bahwa anaknya sudah bisa hidup mandiri, bisa memilih yang terbaik untuk dirinya, meraka berharap anaknya menjadi pribadi yang kuat. Akan tetapi berbeda dengan harapan orang tua. Setelah mereka jauh dari pengawasan orang tua, mereka menjadi bebas dalam melakukan tindakan, membentuk keperibadian berdasarkan apa yang mereka alami sehingga dengan mudahnya mereka mengambil keputusan untuk menjadi waria.

b. Orang tua tidak melarang anaknya bergaul dengan waria
Berdasarkan hasil wawancara yang peneliti lakukan kepada informan diperoleh informasi bahwa mereka dilarang bergaul dengan perempuan akan tetapi orang tua memberi kebebasan kepada mereka untuk bergaul dengan sesama waria.

Dari hasil wawancara dengan informan di dapatkan pernyataan sebagai berikut : "matadda je. Seseheku kkb lebba tekke ka ruma, tidor-tidor manditu, mun ka luahan lahat manseh kkb kami nedu" (Baik-baik saja. Teman-teman waria sering main ke rumah saya, kalau keluar pulau kami selalu bersama sesama waria)

Dari hasil wawancara dengan informan didapatkan pernyataan sebagai berikut :

“ada pergaulan-pergaulan yang menyimpang karna dipengaruhi oleh anak yang berasal dari pulau-pulau yang lain masuk ke daratan sapeken yang memang ketika dilihat secara fisik mereka adalah pejantan atau laki-laki tetapi karakternya menyimpang dari kodratnya sebagai laki-laki”

Sedangkan dari hasil observasi didapatkan bahwa kebanyakan dari keseharian mereka dihabiskan bersama sesama waria, mereka lebih sering bergaul dengan sesama waria daripada bergaul dengan perempuan. Bahkan dari segi pekerjaan rata-rata dari mereka bekerja sebagai tukang hias pengantin. Dalam hal ini, mereka bekerja bersama ketika menghias pengantin dan menghabiskan waktu berlibur bersama sesama waria.

\section{Kekerasan Seksual}

Berdasarkan hasil wawancara dengan informan didapatkan bahwa mereka menolak pelecehan seksual, mereka mengerti bahwa pelecehan seksual itu tidak baik. Bahkan sebaliknya, mereka masing-masing mempunyai pasangan pria yang mereka anggap suami. Dari hasil wawancara tersebut maka peneliti dapat menyimpulakan bahwa secara tidak langsung, pasangan pria yang mereka anggap suami telah melakukan pelecehan seksual hanya saja mereka menikmati keadaan tersebut dengan anggapan hal itu wajar terjadi dengan pasangan suami dan istri.

Dari hasil wawancara secara mendalam dengan waria didapatkan pernyataan seperti berikut : "gai pernah, ngarti jedu ku gai ku adak" (tidak pernah, saya juga mengert, saya tidak mau) "mun gai ka lelle ku iru penno 
essenku, mun ka lelle ku kelli essen ku”(saya kalau tidak main cowok uang saya banyak, kalau saya main cowok uang saya habis).

Sedangkan dari hasil wawancara dengan masyarakat didapatkan pernyataan sebagai berikut: "Gai pernah, juntru iye je norak lelle"(tidak pernah, justru mereka yang mencari pria) Dengan demikian maka dapat ditarik kesimpulan bahwa naluri waria cenderung seperti perempuan sehingga mereka mempunyai ketertarikan kepada laki-laki bukan perempuan. Setelah waria menemukan pasangan laki-laki maka disitulah kekerasan seksual berlangsung akan tetapi mereka tidak menyadari bagaimana proses kekerasan seksual tersebut berlangsung.

\section{Gangguan Kejiwaan}

Berdasarkan hasil wawancara dengan informan didapatkan bahwa mereka seringkali mendengar suara yang membuat mereka tidak nyaman, ada juga yang menyatakan pernah melihat sosok bayangan hitam, tinggi besar yang membuat dirinya tidak nyaman. Dari hasil wawancara dengan waria didapatkan pernyataan sebagai berikut:

"Pernha ku ngite aha lohon, bagal langkau ma dialan ruma kami" (saya pernah melihat sosok hitam, tinggi besar di dalam rumah) "Mun ngite gai pernah. Makale je terrus te tadandanku ore ma ruma"(kalau melihat belum pernah, kalau mendengar sering jika tengah malam sendirian dirumah). Sedangkan berdasarkan hasil Tes Depresion Anxiety Stress Scale (DASS) didapatkan bahwa dari kelima waria yang dipilih sebagai responden dalam penelitian ini masing-masing mendapat skor 48,49,48,51 dan 48. Dengan demikian, maka dapat diketahui bahwa kelima waria dalam penelitian ini mengalami depresi ringan.

Berdasarkan hasil wawancara dengan informan didapatkan bahwa interaksi mereka dengan sesama waria berjalan dengan baik, mereka saling mendukungantar sesama, bekerja bersama dan menghabiskan waktu libur bersama. Begitupun dengan masyarakat, mereka selalu dilibatkan dalam kegiatan masyarakat, bahkan mereka masih sangat dibutuhkan dalam hal kecantikan khususnya menjadi tukang hias pengantin. Sedangkan berdasarkan hasil observasi mereka terlihat selalu bersama bahkan ada yang beberapa dari mereka yang tinggal satu rumah.
Dari hasil wawancara dengan informan didapatkan pernyataan sebagai berikut : "Alhamdulillah matadda je. Nia je dakayu aha gai mabea aku ekka ku lebba palu ne ku mun pupok beke kkb, terrus ku parebean ne. Tapi lau itu gai ne" (Alhamdulillah baik-baik sata. Ada satu orang yang melarang saya, kakak saya kadang mukulin saya kalau kumpul sama waria, dia sering memarahi saya, tapi sekarang sudah nggak) “matadda je. Seseheku kkb lebba tekke ka ruma, tidor-tidor manditu, mun ka luahan lahat manseh kkb kami nedu" (Baik-baik saja. Teman-teman waria sering main ke rumah saya, kalau keluar pulau kami selalu bersama sesama waria)

Berdasarkan hasil wawancara dengan responden didapatkan bahwa mereka sangat mudah mengakrabkan diri dengan teman baru, mereka mengakrabkan diri dengan teman baru seolah-olah mereka sudah lama kenal. Sedangkan berdasarkan hasil observasi didapatkan hasil bahwa mereka sangat percaya diri didepan umum, percaya diri jika berbicara dengan orang lain sehingga memudahkan mereka mengakrabkan diri dengan orang lain dan lingkungan.

Dari hasil wawancara dengan responden didapatkan pernyataan sebagai berikut : "tasikarah aku susuran ka aha lanson akrab $n e$ "(saya butuh ngomong sebentar untuk mengakrabkan diri) "susurang biase. Leba ambangan mun pertama. Ude ru akrabne"(ngomong seperti biasa, kadang malu kalau pertama, habis itu langsung akrab) Sedangkan dari hasil observasi didapatkan bahwa rumah waria seringkali didatangi tamu dari kaum pemuda. Selain itu, waria juga terlihat mudah dalam mengakrabkan diri dengan orang baru, mereka selalu punya topik menarik untuk dibicarakan sehingga banyak orang yang selalu ingin mendengarkan cerita mereka. Hal inilah yang membuat mereka mudal dalam berinteraksi.

Dengan demikian maka peneliti dapat menyimpulkan bahwa waria merupakan mahluk yang unik. Meskipun mereka seringkali dijauhi oleh sebagian kecil masyarakat akan tetapi ada sebagian besar masyarakat yang menganggap mereka menarik untuk ditonton. Hal inilah yang membuat mereka sangat mudah dalam berinteraksi dengan orang baru sehingga mereka merasa mudah menemukan kebahagian dengan 
cara mereka sendiri. Disisi lain, sebagian besar dari mereka mengalami gangguan kejiwaan berupa halusinasi, demikian menurut tes Depresion Anxiety Stress Scale (DASS) menunjukkan bahwa kelima responden dalam penelitian ini mengalami depresi ringan.

\section{PEMBAHASAN}

\section{Pola Asuh Orang Tua}

a. Kurangnya perhatian dari orang tua dalam mengasuh anaknya

Sebagian besar waria hidup terpisah dengan keluarganya, sehingga mereka mempunyai kebebasan dalam menetukan kepribannya. Orang tua waria membirakan mereka hidup secara bebas, hal ini membuka peluang bagi waria untuk sebih sering menghabiskan waktunya bersama dengan sesama waria. Bahkan dari segi pekerjan, kebanyakan dari mereka mempunyai pekerjaan yang sama yaitu sebagai tukang hias pengantin. Sedangkan berdasarkan hasil observasi didapatkan bahwa sebagian besar waria hidup terpisah dengan keluarga dan jauh dari lingkungan keluarga.

"larangan ne jedu ku le emma ku, parebean ne ku soho ne daha battitu beananku ye, gai ku pabeane kukuri beke dende tapi pabea ne ku pupok beke kkb" (sebenarnya orang tua saya melarang saya, memarahi saya, jangan seperti itu saya turuti saja. Saya juga dilarang bergaul dengan perempuan tapi tidak dilarang bergaul dengan sesama waria). (Tanggal 18 Mei 2017). "leba jedu dipabaun ye tapi sanggah sekedar dipabaun"(kadang di kasi tau tapi cuma sekedar dikasi tau)

Remaja perlu dipersiapkan sejak awal baik dari segi mentalnya maupun secara segi keimanannya. Mental remaja diharapkan dapat secara mandiri menyelesaikan masalah yang dihadapinya. Remaja yang tidak bisaberadaptasi dengan peran baru yang dijalaninya maka remaja tersebut tidak bisa menendalikan dirinyadan tidak bisa menahan emosinya.Serta bisa membuat dia stress bahkan depresi. Oleh karena itu diperlukan dukungan dan perhatianpola pengasuhan pada anakdari orang tuanya (Safitry dan Hidayati, 2013).

Pola asuh merupakan bentuk bimbingan dari orang tua terhadap anaknya agar anak tumbuh menjadi pribadi yang baik. Hal ini sejalan denga Euis (2004) yang menyatakan bahwa pola asuh merupakan serangkaian interaksi yang sering atau inten, kedua orangtuanya membimbing anak untuk memiliki kecakapan hidup. Menurut Maccoby (2005),menyatakan bahwacara orang tua mengasuh anaknya dapat menunjukkan gambaraninteraksi orangtua dan anak-anaknya. Orangtua mengekspresikan sikap atau perilaku, nilai dan minat serta harapan dalam proses mengasuh dan memenuhi kebutuhan anaknya.

Berdasarkan uraian diatas dapat diperoleh informasi bahwa peran orang tua sangat dibutuhkan terutama dalam membentuk karakter anak. Anak yang dibiarkan bebas oleh kedua orangtuanya mempresepsikan bahwa anaknya sudah bisa hidup mandiri, dan memilih jalan yang terbaik untuk dirinya, meraka berharap anaknya menjadi pribadi yang kuat. Akan tetapi berbeda dengan harapan orang tua. Setelah mereka jauh dari pengawasan orang tua, mereka menjadi bebas dalam melakukan tindakan, membentuk keperibadian berdasarkan apa yang mereka alami sehingga dengan mudahnya mereka mengambil keputusan untuk menjadi waria. Keabnyakan orangtua menghadapi kesulitan memahami tingkah laku anaknya, terkadang terlihat tidak logis dan tidak sesuai dengan perasaan orang sehat pada umumnya. Dalam memahami anak, membina kehidupan jasmaniah, kecerdasan, perkembangan sosial dan perkembangan emosionalnya, orang tua dituntut untuk mempunyai pengetahuan tentang perilaku mereka.

b. Orang tua tidak melarang anaknya bergaul dengan waria

Sebagai seorang manusia tentu tidak lepas dari pergaulan dan membutuhkan teman untuk berbagi serta saling memahami satu dengan yang lainnya. Pada kasus waria, mereka dilarang bergaul dengan perempun tetapi orang tua tidak melarang jika mereka bergaul dengan sesama waria. mereka saling berinteraksi satu sama lain, saling memberi dukungan sehingga bagi mereka akan lebeih menyenangkan jika waktu keseharian mereka dihabiskan bersama dengan sesama waria.

"matadda je. Seseheku kkb lebba tekke ka ruma, tidor-tidor manditu, mun ka luahan lahat manseh kkb kami nedu" (Baik-baik saja. Teman-teman waria sering main ke rumah saya, kalau keluar pulau kami selalu bersama sesama 
waria) "ada pergaulan-pergaulan yang menyimpang karna dipengaruhi oleh anak yang berasal dari pulau-pulau yang lain masuk ke daratan sapeken yang memang ketika dilihat secara fisik mereka adalah pejantan atau lakilaki tetapi karakternya menyimpang dari kodratnya sebagai laki-laki"

Dari hasil observasi didapatkan bahwa waria lebih sering berkumpul dengan sesama waria daripada dengan perenpuan. Mereka saling berinteraksi satu dengan lainnya setiap hari, bahkan ada beberapa waria yang tinggal satu rumah. Sejalan dengan Sadarjoen (2005) bahwa yang melatariorang tertarik pada sejenisdan waria (menjalanikehidupan sosial dengan menggunakan atribut kewanitaan) yaitu pola asuh orangtua yang ingin memiliki anak perempuan sehingga memakaikana atribut anaknya perempuan pada anak laki-lakinya. Hal ini juga selaras dengan pernyataan Rokhmah (2015), bahwa sebagian kecil rinformalberubah jadi waria karenacara asuh terutama dari cara asuh ibu yang membiasakan anak lelakinya menjadi seperti perempuan.

Kehidupan sesama waria sangat harmonis, mereka bisa saling mengerti satu dengan yang lainnya sehingga mereka lebih memilih untuk menghabiskan waktu mereka sehari-hari bersama dengan sesama waria. Hal inilah yang membuat mereka lebih senang hidup di lingkungan sesama waria daripada di lingkungan keluarga.

\section{Kekerasan seksual}

Kekerasan seksual seringkali terjadi pada waria tetapi mereka tidak menyadari bagaiman kekerasan seksual itu berlangsung. Pada umumnya keperibadian waria sangat mirip dengan keperibadian perempuan sehingga mereka mempunyai anggapan bahwa lakilakilah yang pantas menjadi pasangan hidup mereka. Sebagian besar dari waria mempunyai pasangan laki-laki yang mereka anggap sebagai suami. Keriteria laki-laki bagi waria tidak ada, yang pasti mereka masing-masing mempunyai pasangan laki-laki, dalam hal ini mereka tidak menyadari bahwa kekerasan seksual itu sedang berlangsung tetapi mereka menikmati keadaan tersebut dengan anggapan hal itu wajar terjadi dengan pasangan suami dan istri. "gai pernah, ngarti jedu ku gai ku adak”(tidak pernah, saya juga mengert, saya tidak mau) “mun gai ka lelle ku iru penno essenku, mun ka lelle ku kelli essen ku” (saya kalau tidak main cowok uang saya banyak, kalau saya main cowok uang saya habis) "Gai pernah, juntru iye je norak lelle"(tidak pernah, justru mereka yang mencari pria)

Rahyani (20120, menyatakan bahwaremaja laki-laki, lebih banyak melakukan aktifitas seksual yang dapat membahayakan kesehatnnya daripada pada remaja perempuan. Pernyataan Oetomo (2003), sama dengan perilaku seksual dasarnya, semua bentuk kontak seksual secara langsung diperolehlingkungan mereka yang merupakan homoseks atau penyuka sesama di Indonesia. Penyebab seseorang menjadi penyuka sesama jenis (keadaan dimana seseorang tertarik secara seksual terhadap jenis kelamin sama) dan waria (penyuka sesamayang dalam kehidupan sehariharinya menggunakan aksesoris wanita) yaitu bagaimana cara orang tua mengasuh anak, terutama keluarga yang mengharapkan anak perempuan, akhirnya memperlakukan anak lelakinya diperlakukan sepertianak-anak perempuan (Sadarjoen, 2005).

Kekerasan seksual seringkali terjadi pada waria namun mereka menikmati keadaan dimana mereka seharusnya menyadari bahwa hubungan yang mereka jalani dengan pasangan laki-laki seharusnya tidak ada, mereka beranggapan bahwa hubungan yang mereka jalani bersama pasangan laki-laki sudah sewajarnya terjadi dan bukan merupakan masalah.

\section{Gangguan kejiwaan}

Perlu dilakukan bererapa tahap pengkajian untuk menentukan seseorang mengalami gangguan kejiwaan atau tidak. Salah satunya adalah pengkajian halusinasi. Sebaian besar waria pernah mengalami gangguan halusinasi berupa mendengarkan suara yang tidak jelas asalnya atau pernah melihat sosok yang selalu datang padanya yang dapat mengganggu kenyamanan pada diri waria. "Pernah ku ngite aha lohon, bagal langkau ma dialan ruma kami" (saya pernah melihat sosok hitam, tinggi besar di dalam rumah) "Mun ngite gai pernah. Makale je terrus te tadandanku ore ma ruma" (kalau melihat belum pernah, kalau mendengar sering jika tengah malam sendirian dirumah). 
Dari hasil Tes Depresion Anxiety Stress Scale (DASS) dapat diihat bahawa kelima waria yang terlibat dalam penelitian ini mengalami depresi ringan. dari lima waria, masing-masing waria mendapatkan skor 48,49,48,51 dan 48, dimana menurut kategori DASS skor 30-59 merupakan kategori depresi rinagan. Menurut Safitry dan Hidayati (2013) mengungkapkan bahwa remaja sejak awal harus dimatangkan baik dari segi mental maupun dari segi spiritualnya. Remaja diharapkan dari segi mental dapat menyelesaikan masalah yang dijalani secara mandiri. Remaja yang tidak bisa mengadaptasikan dirinya dengan keadaan baru tersebut, membuat remaja tersebut tidak bisa mengendalikan diri dan emosionalnya bahkan mereka bisa frustasi dan depresi. Tugas-tugas perkembangan yang harus dijalani remaja akan membuat remaja merasa berat dalam melaksanakan peran kehidupannya. Sejalan dengan yang dituliskan oleh Sofia (2009) yaitu keinginan dan permasalahan baik dari segi medis ataupun psikologis dan social mengikutipertumbuhan fisik dari remaja. Kemauan dan permasalahan tersebut dilatari karena keadaan remaja dalam masa penentuan karakter dirinya terhadap norma baru yang adapada lingkungan sekitarnya.

Dengan demikian maka peneliti dapat menyimpulkan bahwa untuk meminimalisir resiko depresi yang terjadi pada waria dibutuhkan peran orang tua dalam bentuk pola asuh yang dapat menggambarkan tingkah laku baik sikap dan perilaku yang dilakukan orang tua pada anaknyasaat berinteraksi danmelakukan komunikasi selama menjalankan kegiatan mengasuh. Dengan demikian maka anak akan merasa diperhatikan oleh orang tua yang kemudia akan membentuk kepribdian yang baik pada anak.

Salah satu kelebihan yang dimiliki oleh seorang waria adalah mereka sangat mudah dalam mengakrabkan diri dengan lingkungan dan teman baru. Dalam kehidupan sehari-hari seringkali kita menemukan sesuatu yang baru, dan berrinteraksi dengan teman baru. Sebagian orang merasa kesulitan dalam berinteraksi dengan teman baru. Berbeda dengan waria, mereka sangat percaya diri ketika berkomunikasi dengan teman baru sehingga memudahkan meraka untuk mengakrabkan diri dengan orang lain.
Kebutuhan untuk diperlakukan secra adil dalam kehidupan bernegara dan bermasyarakat menjadi hak asasi setiap orang. Tetapi pada masyarakat ada sekelompok orang yang dikucilkan atau sengaja tidak didekati karena pernampilan karakter fisiknya. Salah satunya yaitu mereka secara umum dimasyarakat dikenal sebagai wanita tapi pria. Waria adalah satu contoh kaum transseksual yaitu male-tofemale transsexual (Suwarno, 2004).

"tasikarah aku susuran ka aha lanson akrab ne"(saya butuh ngomong sebentar untuk mengakrabkan diri) "susurang biase. Leba ambangan mun pertama. Ude ru akrabne"(ngomong seperti biasa, kadang malu kalau pertama, habis itu langsung akrab). Dari hasil observasi, waria umumnya sangat menarik bagi masyarakat, mereka selalu mempunyai topik menarik untuk dibicarakan. Hal inilah yang membuat mereka mudah dalam berinteraksi dengan orang baru. Selain itu, rumah waria seringkali didatangi tamu dari kaum pemuda, mereka terlihat sangat akrab meskipun tamu tersebut adalah orang baru bagi mereka.

Dari pembahasan diatas dapat diketahui bahwa waria mempunyai kepercayaan diri yang tinggi, hal ini dapat diketahui dari mereka terlibat dalam suatu kegiatan masyarakat dan mampu menarik perhatian banyak orang dengan logat bicara khas waria.

\section{KESIMPULAN}

Pola asuh orang tua terhadap waria sangat maksimal tetapi orang tua tidak pernah memperhatikan dengan siapa saja anaknya berinteraksi. sehingga anak merasa bebas dalam menentukan keperibadiannya.Kekerasan seksual sering kali terjadi pada waria namun mereka tidak menyadari bagaimana proses kekerasan seksual itu terjadi. Sebagian besar waria mengalami gangguan kejiwaan berupa halusinasi dan depresi ringan.

\section{DAFTAR PUSTAKA}

Andarmoyo, S. (2014). Konsep dan Proses Keperawatan Nyeri. Yogyakarta: ArRuzz. Euis, Sunarti. (2004). Mengasuh Anak dengan Hati. Jakarta: PT Elex Media Komputindo.

Faidah. M \& Abdullah. H. (2013). Religiusitas dan Konsep Diri Kaum Waria.JSGI, Vol. 04, No. 01. Surabaya: UIN. 
Gates \& Gary J. (2011). How Many People are Lesbian, Gay, Bisexual and Transgender. UCLA: The Williams Istitute.

Hamid. (2009). Bunga Rampai Asuhan Keperawatan Jiwa. Jakarta: EGC

Kementrian Sosial Republik Indonesia. (2012). Pembangunan Kesejahteraan Sosial. Jakarta: Kementrian Sosial RI.

Potter dan Perry. (2010). Fundamental keperawatan buku 3. Edisi 7. Jakarta: Salemba Medika.

Putri, P. M.T. \& Sutarmanto, H. (2007). Kesejahteraan Subjektif Waria Pekerja Seks Komersial (Psk).Yogyakarta: Universitas Gadjah Mada.

Rokhmah. D. (2015). Jurnal Kesehatan Masyarakat. Jember: http://journal.unnes.ac.id/nju/index.php/ kemas

Ruhghea S, dkk. (2014). Studi Kualitatif Kepuasan Hidup Pria Transgender
(Waria) Di Banda Aceh Program Studi Psikologi Fakultas Kedokteran Universitas Syiah KualaDarussalam Banda Aceh. Banda Aceh:Universitas Syiah Kuala.

Sadarjoen, S.S. (2005). Bunga Rampai Kasus Gangguan Psikoseksual. Bandung : PT. Refika Aditama.

Safitri dan Hidayati. (2013). Hubungan Antara Pola Asuh Orang Tua Dengan Tingkat Depresi Remaja Di SMK 10 November. Semarang: UNIMUS

Sofia, R. (2009). Peranan Keberfungsian Keluarga pada Pemahaman dan Pengungkapan Emosi. Jurnal Psikologi. Stuart, G.W. (2013). Buku Saku Keperawatan Jiwa, ed 5. Jakarta: EGC Suwarno. (2004). Transeksual Minoritas yang Terlupakan. Kompas 26 Juli. 